\title{
THE RELATIONSHIP BETWEEN FINANCIAL LEVERAGE AND LIQUIDITY, AND FIRMS' PROFITABILITY OF THE AGRICULTURAL INDUSTRY: EVIDENCE FROM MALAYSIAN LISTED FIRMS
}

\author{
Muhamad Adhwa Zulkipli', Nik Anis Idayu Nik Abdullah ${ }^{2}$ \\ and Amrizah Kamaluddin ${ }^{3}$ \\ ${ }^{1}$ Banking Supervisor, Central Bank of Malaysia, \\ Jalan Dato' Onn, 50929 Kuala Lumpur \\ E-mail: adhwa@bnm.gov.my \\ ${ }^{2}$ Faculty of Accountancy, UiTM Selangor, Kampus Puncak Alam, \\ E-mail: nikanis0208@uitm.edu.my \\ ${ }^{3}$ Associate Professor, Faculty of Accountancy, UiTM Selangor, Kampus Puncak Alam, \\ E-mail: amrizah@uitm.edu.my
}

\begin{abstract}
This study examined the relationship between financial leverage and liquidity with firms' profitability of the Malaysian agricultural industry between 2011 to 2015. Additionally, the study attempted to examine the ability of both financial leverage and liquidity in predicting firms' profitability. Financial ratios of 40 agriculturural firms' that were listed in the Bursa Malaysia Main Board were taken as the sample. The selected variables for the study were Debt Equity Ratio (DTE), Interest Coverage Ratio (ICR), Proprietary Ratio (PR), Current Ratio (CuR), Quick Ratio (QR) and Cash Ratio (CsR) as the independent variables whilst Return on Capital Employed (ROCE) was the dependent variable. The study discovered that significant relationships exists between both financial leverage and liquidity and firm profitability. In addition, both financial leverage and liquidity are also significant to explain and predict firms profitability. The results confirm the trade-off theory, which suggests that firm profitability would increase as the level of debt increases, but only to an optimal level where any subsequent increment in the firms' debt level upon reaching its optimal level would result in the contraction of its profitability.
\end{abstract}

Keywords: financial leverage, liquidity ratio, firm's profitability, agriculture firms

ARTICLE INFO

Article History:

Received: 1 August 2019

Accepted: 7 November 2019

Published: 31 December 2019 


\section{INTRODUCTION}

In the recent economic environment, firms are exposed to all kinds of risks and threats that could bring down performance, especially profitability performance. There are various measures used by previous researchers or business analysts in projecting and forecasting firm performance, which also includes financial distress conditions. One of the most popular methods is by analyzing firms' historical financial ratios in examining the potential of such ratios with financial performances. For instance, Altman (1968), Ohlson (1980), Lewellen (2004) and Wijesundera, Weerasinghe, Krishna, Gunawardena, and Peiris (2016), all used financial ratios in predicting firms profitability and bankruptcy. This has proven that financial ratio has been the preference of past researches for decades. Firm performance is typically measured by its profitability level as well as its assets growth for the financial year. Additionally, analysts and researchers would associate firm performances by linking it with the firm strategies in managing business operations as financial leverage as well as financial liquidity practices.

According to the National Statistic Department, in 2014, the Malaysian economy rose to about 6.0 per cent as compared to 4.7 per cent recorded in 2013, whereby in terms of industry share, the agricultural sector contributed about 9.2 per cent to the national Gross Domestic Product (Dardak, 2015). As of now, the agricultural industry continues to play its role as the one of major contributors to the national economy. The agricultural sector initially originated from the surge in the production of livestock, fisheries, and other miscellaneous crops. The agricultural sector has more valuable cash crops owing to the increase in earnings from major commodities such as rubber, palm oil, and food commodities. It has enabled the sector to retain its workforce and shore up the economic downturn of the 1997 financial crisis.

The reason of selecting the Agricultural industry for the purpose of this study was due to its significant contribution towards the national GDP and the total employment opportunity that it provides to the Malaysian population. Past studies were mostly confined to the more mainstream industries with very minimal studies conducted on the less popular industry such as agriculture, textile and entertainment. The nature of business operations in the Agricultural industry is considerably unique from other industries, for instances, the stock assets could only be ready upon the 
crops when they reached the maturity level, high dependency on weather and seasonal conditions, high cost of capital expenditure, allocation of resources by authorities, and fluctuation in the commodity market prices. These to large extent would expose the agricultural based companies to have a comparatively higher leverage level as compared to the other industries.

Past studies particularly in the areas of relationship between financial leverage and liquidity, and firm profitability were mainly confined towards other mainstream industries such as the financial services industry (ChanLau et al., 2015), cement industry (Ertuğrul \& Karakaşoğlu, 2009), manufacturing industry (Nishanthini \& Nimalathasan, 2013), hotel industry (Sheel, 1994), restaurant industry (Yoon \& Jang, 2005), chemical industry (Khidmat \& Rehman, 2014), and property and real estate industry (Rudin et al., 2016). However, the findings by all this researchers vary and hence reflect different economic conditions of respective countries.

This study would provide a view on the real situation faced by firms involved in the agricultural industry. The importance as well as the significant contribution of this study to the industry would be clear evidence in promoting more research to be performed in this industry. The government, especially the ministry in-charge of agriculture administration would benefit from this study in ensuring the sustainability of the firms to improve their earnings performance and subsequently contribute to the national GDP to a large extent. Additionally, the results of this study could play a role in instilling confidence of investors to consider investing in the agricultural industry. This would eventually help in rejuvenating the overall industry and hence boost the nation's GDP.

\section{LITERATURE REVIEW}

\section{Trade-off Theory}

According to the trade-off theory, in achieving a suitable capital structure, firms essentially need to successfully balance the capital structure component costs. In other words, firms would enjoy a higher value or higher profits arising from good debt management strategies only up to the optimal leverage point where any increase in the financial leverage level subsequent 
to this optimal point would lead to a drop in firm value. Myers (1984) suggested that the trade-off between the tax benefits of debt and the financial distress costs are expected to yield the debt optimal level to maximize firm value. This can be realized by producing a balance between the tax savings that arise from debt, thereby reducing agency costs, bankruptcy threat and financial distress (Ayen \& Oruas, 2008). In addition, the benefits derived from maximising a firm's value, as proposed by the trade-off theory, can be transacted for the issuing debt cost. In other words, the benefits of the trade-off theory are traded against their costs to maximise the value of the firm. The Malaysian tax system maintains its own uniqueness as there are numerous tax incentives offered to companies involved in agriculture-based activities. It ranges from exploring new sites, timbering, research and development, up to food production. Thus, the tax system in Malaysia has its own effects that may lead to a conclusion about the trade-off theory that is different from the conclusion reached for Western tax systems.

\section{Overview of Malaysia Agricultural Industry}

The agricultural industry, since the era of the 70s has contributed significantly to the development of the Malaysian economy. Malaysia was once the largest exporter of many agricultural products such as rice, rubber and palm oil before other countries that saw the prospects of this sector.e. The agricultural industry was also a savior to the country's economy during the Asian financial crisis in 1997, where the Ringgit was inflated to the very worst level ever. This is due to the lower level of dependency on the oil and gas sector and financial services which suffered the most during the crisis. The agricultural industry has contributed to the growth and continued to be a major contributor to the national income as well as export earnings. It has become a basis of economic growth as well as the main contributor to the national economy prior to the 1970s. Dardak (2015) revealed that the agricultural industry contribution towards the Malaysian GDP had increased from RM51.3 billion in 2010 to almost RM56.0 billion in 2013.

The agricultural industry initially originated from the surge in the production of livestock, fisheries, and other miscellaneous crops. The agricultural sector has more valuable cash crops owing to the increase in earnings from major commodities such as rubber, palm oil, and food commodities. It has enabled the sector to retain its workforce and shore 
up the economic downturn of the 1997 financial crisis. As of now, the agricultural industry continues to play its role as one of the major contributors to the nation's economy. Based on the statistics released by the office of Chief Statistician Malaysia (2015), Malaysia's economy rose to about 6.0 per cent as compared to 4.7 per cent recorded in 2013, whereby in terms of industry share, the agricultural sector contributed to about 9.2 per cent to the national Gross Domestic Product (GDP).

\section{Underlying Principle of Financial Leverage, Liquidity and Firm Performance}

Financial leverage and liquidity are common predictors that were used by previous researchers in predicting firm performance. This is in line with the trade-off theory of the capital structure which explained that a firm would normally decide on how much debt and equity finance is to be used in its operations by way of balancing the costs and also the benefits deriving from such strategies. The strategies can be measured through financial leverage ratios which indicate the degree of reliance on debt or equity. Although liquidity was not been mentioned in the overall idea of the trade-off theory of the capital structure, it can also be linked with the firm's debt management strategy in such a way that firms typically would invest their available funds towards less liquid assets in order to enjoy higher returns, and most importantly to generate sufficient returns to repay its debt obligations.

Additionally, based on the concept of the trade-off theory cost of capital, the high liquidity ratio demonstrates the firm's ability to satisfy its short-term liabilities, supported by the positive relationship between liquidity and leverage (Butt et al., 2013). Although the investment made on high liquid assets would provide a cushion for firms during stressed economic conditions, liquid assets are comparatively less profitable to long term assets. It has always been a dilemma for most finance managers on whether to invest in illiquid long term assets which are more profitable and give rise to the firms liquidity risk, or to invest in short term assets which will lower firms liquidity risk and to a certain extent affect firm profitability, given its less profitable nature (Karani, 2014). Ideally, it can be said that financial leverage tends to have a negative relationship towards firm profitability whilst liquidity would have a tendency of having a positive 
relationship with firm' profitability. Examples of previous studies which have applied both financial leverage ratios and liquidity ratios as a determinant of firm profitability are Khidmat and Rehman (2014), Kyule (2015), and Rudin et al. (2016).

Khidmat and Rehman (2014) suggested that liquidity management is important for every organization in ensuring its ability to repay its current business obligations, which includes operating and financial expenses. The results showed that the solvency ratio (or known as leverage ratio) has a high negative impact on firm profitability, measured by ROA and ROE. Additionally, liquidity has shown a high positive effect on firm performance which is in tandem with the findings of Saleem and Rehman (2011).

Similarly, Kyule (2015) in his study to investigate the impact of solvency and liquidity on firms' financial performance listed in the Nairobi Securities Exchange suggested that the firms' performance is highly dependent on its ability to exhibit attractive financial ratios of both solvency and liquidity as desired by the stakeholders. The study performed by Kyule (2015) covered a period of five years from 2009 to 2013, and the findings showed that liquidity has a positive impact on the firms performance. Solvency on the other hand, exhibited a negative affect towards firm performance although the effect is not statistically significant.

Rudin et al. (2016) in examining the relationship and impact of financial leverage and liquidity on Indonesian real estate and property listed firm performance for the period of six financial years revealed that leverage and liquidity simultaneously showed a significant effect on firm profitability. In a separate model, liquidity alone showed an effect partially on firm profitability, at the non-significant effect level. Meanwhile, financial leverage showed a significant effect on firm profitability partially.

\section{HYPOTHESES DEVELOPMENT}

There are many experimental studies performed on the relationship between firm leverage and profitability with various findings derived from these studies. Some studies have found positive relationships, while others discovered negative relationships. Studies by Ruland and Zhou (2005), 
and Robb and Robinson (2012), revealed a positive relationship between firm leverage and profitability. Jensen (1986) claimed that profitable firms demonstrated quality by leveraging up, which resulted in a positive relationship between profitability and leverage. His findings are parallel with Modigliani and Miller (1963). Robb and Robinson (2012) on the other hand found that financial gains from leverage are relatively significant, and the market value of firms was enhanced by the use of debt. Consistently, Chandrakumarmangalam and Govindasamy (2010) discovered that profitability is positively related to firm leverage, and as the firms employed more debt, shareholders wealth is maximized.

Some studies have found a negative relationship between firm leverage and profitability such as Myers (1984); Phillips and Sipahioglu (2004) and Negash (2001). Furthermore, Nawaz et al. (2015) revealed that financial leverage position has showed a statistically significant converse impact on firm profitability at the $99 \%$ confidence level particularly due to higher borrowing cost commitments. Arising from this, the first hypothesis between financial leverage and firm profitability for this study can be written as follows:

$\mathbf{H}_{\mathbf{1}}$ : Financial leverage has a significant relationship with firm profitability

For the first hypothesis, three financial leverage ratios namely Debtto-Equity ratio, Interest Coverage Ratio, and Proprietary ratio were used to test firm profitability, measured by the Return on Capital Employed. Debt-to-Equity ratio is a common debt-based ratio that was used in most studies which examined the relationship between firm profitability and debt management practices. For instance, Wippern (1966) found a positive relationship between firm debt and profitability for different industries, by using debt-to-equity and earning to market ratio as the independent variables. The results were also consistently agreed by Khidmat and Rehman (2014) through their study on the impact of solvency and liquidity on firm profitability in the Pakistan chemical sector, where it was found that the solvency ratio measured by Debt to Equity among its independent variables, has a significant negative impact on the firm profitability.

The Interest Coverage Ratio was also commonly used in previous studies as a proxy of firm leverage in examining the impact against 
firm profitability. Khidmat and Rehman (2014) also discovered that the Interest Coverage Ratio as a proxy of financial leverage exhibited a negative impact on the firm performance. The argument was also supported by the study by Nimalathasan and Brabete (2010) on the impact of the capital structure on Sri Lankan manufacturing firm profitability. The study discovered that the interest coverage ratio is significantly correlated to the firm profitability, measured by ROCE and NPR.

The Proprietary ratio or also known as the equity ratio on the other hand provides a different view, although it is also commonly regarded as one of the financial leverage ratio. Different from the Debt to Equity and Interest Coverage Ratio, proprietary ratios emphasized on the concentration towards the use of equity as a firm's source of funds. Indicatively, the higher the proprietary ratio, the higher the profitability would be, as relatively low interest expense is to be paid from debt commitments.

The second hypothesis, includes the idea that; if the firm has lower liquid assets, evidenced by a high liquidity ratio amount, it will have a higher profitability due to the fact that more monies / capital can be used to invest in the less liquid assets which have a high profit margin. Vice versa, if the firm holds a high amount of liquid assets, the profit generated would be lower. This is in line with past studies performed by Eljelly (2004) which studied the relationship between firm liquidity against the state of profitability and found a significant negative relationship between the two. In addition, Owolabi et al. (2011) investigated the relationship between profitability and liquidity in selected Nigerian quoted companies by using Correlation and multiple regression analysis to further determine whether any potential cause and effect relationship exists between them. Similarly, Bhunia et al. (2011) in identifying the degree of working capital effectiveness in terms of short-term liquidity of India's private sector steel firms revealed a significant correlation and positive significant regression results. Thus, the second hypothesis can be written as follows:

$\mathbf{H}_{2}$ : Liquidity ratio has a significant relationship with firm profitability

For the second hypothesis, liquidity with proxies of three ratios, namely Current ratio, Quick Ratio, and Cash ratio, whilst firm profitability was measured by Return on Capital Employed. Current Ratio is the most 
popular ratio in the areas of finance-related research to proxy the firm liquidity ratio, particularly in examining the relationship against firm profitability. For instance, Priya and Nimalathasan (2013) in their study to examine the relationship between liquidity and Sri Lankan manufacturing firm profitability found that Current Ratio (CR) is significantly correlated with firm profitability. In line with this, Ben-Caleb et al. (2013) in their study of the relationship between liquidity management and profitability of Nigerian manufacturing companies revealed a similar relationship where current ratio is positively associated with the firm profitability.

The component of quick ratio is almost similar with current ratio except for the exclusion of the inventories element from the formula's numerator. There are some studies that applied both the current and quick ratio proxies of liquidity ratios. However, there were also studies which only applied only the quick ratio to represent the liquidity ratio. For instance, Dahiyat (2016) in his study of the relationship between liquidity and solvency ratios and Jordan's listed banks' performance revealed that liquidity with quick ratio as the proxy exhibited a significant negative impact on bank profitability. Meanwhile, Khan and Mutahhar Ali (2016) used both the current and quick ratio as proxies of liquidity ratio in examining the impact of liquidity on Pakistan Commercial bank profitability.It was discovered that there is a significant positive relationship between bank profitability and liquidity.

Cash ratio is another type of liquidity ratio which further refines the definition of both the current and quick ratio by considering only the amount of cash, cash equivalents and invested funds as the current assets over firms' current liabilities. Although it seems to be a popular tool for liquidity measurement, there were some studies which applied this ratio alongside with other types of liquidity ratios such as current and quick ratios. For instance, Khaldun and Muda (2014) in examining the influence of liquidity and profitability ratios on the profit growth of Indonesian manufacturing companies used Cash Ratio as part of Liquidity ratios, where it was discovered that all liquidity ratios including cash ratio, current ratio, and quick ratio have a significant influence towards the growth of profit. 


\section{METHODOLOGY}

A census sampling technique was applied to this study as there were only 41 agricultural companies listed on the main board of Bursa Malaysia. However, only 40 agriculture-based companies were included, in view of the litigation status faced by one exclusion company, resulting in its financial information to be suspended from being publicised in the Bursa Malaysia website. Independent variables of six financial ratios and two ratios for the dependent variables, with 5 a year historical data from the end of the 2011 financial year to the financial year ending in 2015, were taken to form the total sample size and tested. Natural log transformation and outlier elimination was performed to address the data non-normality issue. For the purpose of this study, financial data were gathered from secondary sources that is from the external data provider, Thomson Reuters. For any particular sample items which were not available from the data provider, manual extraction from the firms' annual report publicised at the Bursa Malaysia website were considered.

\section{EMPIRICAL RESULTS AND DISCUSSION}

\section{Pearson's Correlation}

Table 1: Pearson's Correlation

\begin{tabular}{llllllllll}
\hline \multicolumn{1}{c}{ Variables } & $\mathbf{1}$ & $\mathbf{2}$ & $\mathbf{3}$ & $\mathbf{4}$ & $\mathbf{5}$ & $\mathbf{6}$ & $\mathbf{7}$ & $\mathbf{8}$ \\
\hline 1 & Log_ & 1 & & & & & & & \\
& ROCE & & & & & & & & \\
2 & Log_DTE & $.318^{* *}$ & 1 & & & & & & \\
3 & Log_PR & -.132 & $-.865^{* *}$ & 1 & & & & & \\
4 & Log_ICR & $.395^{* *}$ & $-.485^{* *}$ & $.576^{* *}$ & 1 & & & & \\
5 & Log_CuR & -.123 & $-.833^{* *}$ & $.752^{* *}$ & $.627^{* *}$ & 1 & & & \\
6 & Log_QR & -.117 & $-.818^{* *}$ & $.728^{* *}$ & $.653^{* *}$ & $.976^{* *}$ & 1 & & \\
7 & Log_CsR & -.107 & $-.757^{* *}$ & $.680^{* *}$ & $.555^{* *}$ & $.928^{* *}$ & $.960^{* *}$ & 1 & \\
8 & Log_Size & $.234^{* *}$ & $.288^{* *}$ & $-.291^{* *}$ & -.028 & -.010 & -.028 & -.049 & 1 \\
\hline
\end{tabular}

Pearsons's Correlation was predominantly performed to establish the direction as well as the association strength between model variables. According to rule of thumb of the Guilford's Rule, the relationship strength 
can be regarded as very high ( $>0.9)$, high $(0.7-0.9)$, moderate $(0.4-0.7)$, low $(0.2-0.4)$, and negligible $(<0.2)$. Table 4 above represents the Persons's Correlation analysis results for all the variables used in this study (Hinkle et al., 2003).

The results exhibited that all the variables have a relationship or association with each other with the strongest relationship noted between Log_CuR and Log_QR with the value of 0.976 units. It can be further interpreted by saying that; an increase in 0.976 units of the Current Ratio will result in an increase of the Quick Ratio by the same unit amount. The result however, is explainable given that the formula for both Current and Quick ratio is almost similar, with the only difference of deduction of inventories assets in the Quick ratio numerator.

The table also indicates that ROCE is a dependent variable which has a negative association with all liquidity ratios, with the value denoted in negative form. This is in line with the return of high liquid assets which would generate a lower return compared to less liquid assets. Indirectly, it could be stated that any increase in firms' liquidity position to a certain extent would bring down firm profitability performance. The results generated in Table 1 would also be used in interpreting the Multiple Linear Regression results in the following section of thispaper.

\section{Multiple Linear Regressions}

The multiple linear regressions were performed for ROCE as dependent variable.

Table 2: Model Summary ${ }^{\mathrm{b}}$ : The Relationship between IVs and ROCE

\begin{tabular}{ccccc}
\hline Model & $\mathbf{R}$ & R Square & $\begin{array}{c}\text { Adjusted } \mathbf{R} \\
\text { Square }\end{array}$ & $\begin{array}{c}\text { Std. Error of the } \\
\text { Estimate }\end{array}$ \\
\hline 1 & $.750^{\mathrm{a}}$ & .563 & .537 & .294534 \\
\hline
\end{tabular}

a. Predictors: (Constant), Log_CsR, Log_Size, Log_ICR, Log_PR, Log_DTE, Log_CuR, Log_QR

b. Dependent Variable: Log_ROCE 
Table 3: Analysis of Variance (ANOVA ${ }^{a}$ ) : Relationship between IVs and ROCE

\begin{tabular}{ccccccc}
\hline Model & $\begin{array}{c}\text { Sum of } \\
\text { Squares }\end{array}$ & df & $\begin{array}{c}\text { Mean } \\
\text { Square }\end{array}$ & F & Sig. \\
\hline 1 & Regression & 13.304 & 7 & 1.901 & 21.908 & $.000^{\text {b }}$ \\
\cline { 3 - 4 } & Residual & 10.323 & 119 & .087 & & \\
\multicolumn{1}{c}{ Total } & 23.627 & 126 & & & \\
\hline
\end{tabular}

Dependent Variable: Log_ROCE

Table 4: Multiple Linear Regression Result: Relationship between IVs and ROCE Coefficients ${ }^{a}$

\begin{tabular}{ccccccc}
\hline \multicolumn{1}{l}{$\begin{array}{l}\text { Model } \\
\text { B }\end{array}$} & \multicolumn{2}{c}{$\begin{array}{c}\text { Unstandardized } \\
\text { Coefficients }\end{array}$} & $\begin{array}{c}\text { Standardized } \\
\text { Coefficients }\end{array}$ & $\mathbf{t}$ & Sig. \\
\hline 1 Std. Error & Beta & & & \\
\hline & (Constant) & -2.376 & .434 & & -5.470 & .000 \\
& Log_Size & .135 & .067 & .147 & 2.033 & .044 \\
Log_DTE & .304 & .122 & .423 & 2.488 & .014 \\
Log_ICR & .578 & .062 & .893 & 9.312 & .000 \\
Log_PR & .131 & .523 & .034 & .251 & .802 \\
Log_CuR & .272 & .207 & .401 & 1.313 & .192 \\
Log_QR & -.913 & .253 & -1.563 & -3.602 & .000 \\
Log_CsR & .393 & .116 & .831 & 3.378 & .001 \\
\hline
\end{tabular}

a. Dependent Variable: Log_ROCE

b. Predictors: (Constant), Log_CsR, Log_Size, Log_ICR, Log_PR, Log_DTE, Log_CuR, Log_QR

Normality was performed on all variables which included all three ratios that represented leverage ratios as the first independent variable (Interest Coverage Ratio, Debt-to-equity ratio and Proprietary ratio), three ratios under liquidity ratios for the second independent variable (Current ratio, Quick ratio, and Cash ratio), as well as the variable that represents the profitability ratio as a dependent variable (Return on Capital Employed). As the sample size was extensive as it included a 5 year period data across 40 agricultural companies that were listed under the main board of Bursa Malaysia, there were some non-normality issues noted. To overcome this, data under all variables were transformed into a $\log 10$ form under the SPSS $\log$ transformation method to ensure that the data is in a more interpretable manner as well as to meet the underlying assumptions of inferential statistics. 
Additionally, according to Azzalini and Dalla (1996), log transformation is a common statistical method used to cure data non-normality issues.

Multiple regression analyses were conducted to examine the relationship between firm profitability which was represented by ROCE and various potential predictors' with firm financial leverage and liquidity level as proxies. The multiple regression model with all six predictors produced $\mathrm{R}^{2}=.563, \mathrm{~F}(4,119)=21.91, \mathrm{p}<.001$. It can be interpreted that the models significantly reflect its ability to predict the outcome variable. The results can be viewed in Table 2. Meanwhile, adjusted R2 value of .537 as per Table 2 indicate that this model accounts for $53.7 \%$ of the total variability in predicting the dependent variable.

As can be seen in Table 1 (Pearson Correlation), the DTE and ICR show significant positive regression weights, which indicate that firms with higher values on these ratios were expected to have higher profitability ratios as in ROCE, after controlling for other variables in this model. Indirectly, the positive and significant relationship shown by DTE and ICR with the firms' ROCE conform the idea of the trade-of theory, whereby firm profitability would be rejuvenated by the increase in debt commitment, but only up to an optimal level, where the profitability will start to shrink once the optimal level has been reached. The remaining predictors $(\mathrm{CuR}, \mathrm{QR}$, CsR and PR) have demonstrated a non-significant negative weight with the firms' ROCE indicating that if there is any increase in $\mathrm{CuR}, \mathrm{QR}, \mathrm{CsR}$, and PR, it would result in a decreasing ROCE, at a non-significant level. Firm size has recorded a significant coefficient value of .234 (significant at p-value $<.01$ ) indicating that the firm size has apositive and significant relationship with the firms' ROCE.

Based on Table 4, the significant value (or p-value) indicates the degree of significant relationship between independent variables (or predictors) with dependent variable (or criterion) which could be explained by using the rule of thumb p-value $<.05$. The result, based on the Table 4, has successfully met the hypotheses of this study where the ICR, DTE, QR and CsR exhibited a significant relationship with firms' ROCE. In other words, it suggests that, based on this model, ICR, DTE, QR, and CSR is significant to explain the firms' ROCE. Notwithstanding that, firm size has also demonstrated a significant relationship with the ROCE, evidenced by 
its value of .044 ( $\mathrm{p}$-value <.05). The multiple regression model equation for model 1, hence can be expressed as follows:

$$
\begin{aligned}
& \text { Log_ROCE }=-2.376+.135\left(\log \_ \text {Size }\right)+0.304\left(\log _{-} \text {DTE }\right)+0.578(\log \\
& I C R)+0.131\left(\log _{-} P R\right)+0.272\left(\log \_C u R\right)-0.913\left(\log _{-}\right. \\
& \mathrm{QR})+0.3937\left(\log \_ \text {CsR }\right)+\mathrm{e}
\end{aligned}
$$

\section{CONCLUSION}

This study aimed to examine the relationship of financial leverage and liquidity management practices on the agriculture sector firms' profitability which are registered on the main board Malaysia stock exchange, also known as Bursa Malaysia. The idea of choosing the agriculture industry was due to the minimal number of studies that have been performed on this industry, although the agricultural industry has played important roles in the national economy. In achieving this study objective, multiple linear regression tests were conducted where financial leverage and liquidity management practices with six financial ratios namely Debt-to-Asset ratio (DTE), Interest Coverage Ratio (ICR), Proprietary Ratio (PR), Current Ratio (CuR), Quick Ratio (QR) and Cash Ratio (CsR) acted as the proxies whilst firms' profitability as the dependent variable was proxied by Return on Capital Employed (ROCE). Firm assets with firms' total assets as the proxy was used as the Control Variable.

Based on the multiple regression conducted, only Debt to Equity ratio (DTE), Quick ratio (QR), Interest Coverage Ratio (ICR) and Cash ratio (CsR) showed a significant relationship with firms' Return on Capital Employed (ROCE) at a significant value of less than .05 (p-value $<.05$ ). In other words, it can be said that all this four ratios DTE, QR, ICR and CsR are significant to explain the firms' ROCE.

Hence, it can be concluded that both the main hypotheses (H1: Financial leverage has a significant relationship with firm's profitability, and H2: Liquidity ratio has a significant relationship with firms' profitability were partially met, having the fact that only four out of six proxies for the independent variables under both the main hypotheses $\mathrm{H} 1$ and $\mathrm{H} 2$ were successfully met. The result is also consistent with the study performed 
by Habib et al. (2016) in examining the impact of debt on Pakistani nonfinancial sector firm profitability where it revealed a significant negative relationship between total debt, long term debt and short term debt, and return on assets. Additionally, Saleem and Rehman (2011) in the study of Impacts of liquidity ratios on profitability revealed that the liquidity ratios (with three liquidity ratios as the proxies) shows a significant impact on firm profitability, which agrees with the findings generated in this study.

Main limitation include the overall framework of this study involved an analysis of financial statements that only focused on financial leverage and liquidity as a predictor or independent variables, and ignoring other parts such as financial efficiency and market ratio, which could also be used as independent variables or predictors of firm profitability. Additionally, the study ignored other non-financial factors that could act as a potential reliable predictor for agriculture firm profitability, i.e. geographical locations, number of years in business, types of agriculture activities and others. In view of the limitations identified, several initiatives could be taken to further improve the study as well as to make it more meaningful to the audience. Firstly, the framework could also consider other types of financial ratios that could be used as potential predictors of firm performance. This among others is simply by including the financial efficiency ratio, market ratio and solvency ratio which is normally used by the analysts or financial controllers in assessing firm's annual performance on a periodic basis. In addition to financial ratios, non-financial information could also be considered as a predictor of firm performance which may provide more reliable and significant results as compared to financial ratios. Among non-financial information that could be considered are number of years in business operations, type of agriculture based activities, geographical location of business operations, changes in national tax policy changes, and others.

\section{REFERENCES}

Altman, E. I. (1968). Financial ratios, discriminant analysis and the prediction of corporate bankruptcy. The Journal of Finance, 23(4), 589-609. 
Ayen, M. \& Oruas, E. (2008). Testing of pecking order theory in ISE (Istanbul stock exchange market). International Research Journal of Finance \& Economics, 21, 19-26.

Ben-Caleb, E., Olubukunola, U., \& Uwuigbe, U. (2013). Liquidity management and Profitability of manufacturing companies in Nigeria. Journal of Business and Management, 9, 13-21.

Bhunia, A., Khan, I., \& MuKhuti, S. (2011). A study of managing liquidity. Journal of Management Research, 3(2), 1-22.

Bonazzi, G., \& Iotti, M. (2014). Interest coverage ratios (ICRs) and financial sustainability: Application to firms with bovine dairy livestock. American Journal of Agricultural and Biological Sciences, 9(4), 482-489.

Butt, S., Khan, Z. A., \& Nafees, B. (2013). Static trade-off theory or pecking order theory which one suits best to the financial sector: Evidence from Pakistan. European Journal of Business and Management, 5(23), 131-140.

Chandrakumarmangalam, S., \& Govindasamy, P. (2010). Leverage-An analysis and its impact on profitability with reference to selected cement companies in India. European Journal of Economics, Finance and Administrative Sciences, 27, 53-66.

Chan-Lau, J. A., Liu, E. X., \& Schmittmann, J. M. (2015). Equity returns in the banking sector in the wake of the Great Recession and the European sovereign debt crisis. Journal of Financial Stability, 16, 164-172.

Dalnial, H., Kamaluddin, A., Sanusi, Z. M., \& Khairuddin, K. S. (2014). Detecting fraudulent financial reporting through financial statement analysis. Journal of Advanced Management Science, 2(1), 17-22.

Dardak, R. A. (2015). Transformation of Agricultural Sector in Malaysia through Agricultural Policy. Malaysian Agricultural Research and Development Institute (MARDI), Malaysia, 7. 
Eljelly, A. M. (2004). Liquidity-profitability tradeoff: An empirical investigation in an emerging market. International Journal of Commerce and Management, 14(2), 48-61.

Eriotis, N. P., Frangouli, Z., \& Ventoura-Neokosmides, Z. (2011). Profit margin and capital structure: an empirical relationship. Journal of Applied Business Research (JABR), 18(2), 85-88.

Ertuğrul, İ., \& Karakaşoğlu, N. (2009). Performance evaluation of Turkish cement firms with fuzzy analytic hierarchy process and TOPSIS methods. Expert Systems with Applications, 36(1), 702-715.

Habib, H. J., Khan, F., \& Wazir, M. I. (2016). Impact of debt on profitability of firms: Evidence from non-financial sector of Pakistan. City University Research, 6(1), 70-80.

Hinkle, D. E., Wiersma, W., \& Jurs, S. G. (2003). Applied statistics for the behavioral sciences. Boston, MA: Houghton Mifflin.

Karani, R. M. (2014). The effect of liquidity management on profitability of commercial banks in Kenya (Doctoral dissertation, University of Nairobi).

Khaldun, K. I., \& Muda, I. (2014). The influence of profitability and liquidity ratios on the growth of profit of manufacturing companies: a study of food and beverages sector companies listed on Indonesia stock exchange (period 2010-2012). International Journal of Economics, Commerce and Management, 2(12), 1-17.

Khan, A., \& Mutahhar Ali, R. (2016). Impact of liquidity on profitability of commercial banks in Pakistan: An analysis on banking sector in Pakistan. Global Journal of Management and Business Research, 16(1), 53-59.

Khidmat, W., \& Rehman, M. (2014). Impact of liquidity and solvency on profitability chemical sector of Pakistan. Economics Management Innovation, 6(3), 34-67. 
Kyule, J. M. (2015). Impact of liquidity and solvency on financial performance of firms listed at the Nairobi securities exchange (Doctoral dissertation, University of Nairobi).

Lee, J. E. (2016). Audit quality and accrual reliability: Evidence from the Korean Stock Market. Journal of Applied Business Research (JABR), 32(3), 777-790.

Lewellen, J. (2004). Predicting returns with financial ratios. Journal of Financial Economics, 74(2), 209-235.

Myers, S. C. (1984). The capital structure puzzle. The Journal of Finance, 39(3), 574-592.

Nawaz, A., Salman, A., \& Shamsi, A. F. (2015). Impact of financial leverage on firms' profitability: An investigation from cement sector of Pakistan. Research Journal of Finance and Accounting, 6(7), 75-80.

Nazir, M. S., \& Afza, T. (2009). Impact of aggressive working capital management policy on firms' profitability. IUP Journal of Applied Finance, 15(8), 19-30.

Negash, M. (2001). Debt, tax shield and bankruptcy costs: Some evidence from JSE. Investment Analysts Journal, 30(54), 33-44.

Nimalathasan, B., \& Brabete, V. (2010). Capital structure and its impact on profitability: A study of listed manufacturing companies in Sri Lanka. Young Economists Journal / Revista Tinerilor Economisti, 1(15), 7-16.

Nishanthini, A., \& Nimalathasan, B. (2013). Determinants of profitability: A case study of listed manufacturing companies in Sri Lanka. Journal of Management, 8(1), 42-50.

Owolabi, S. A., Obiakor, R. T., \& Okwu, A. T. (2011). Investigating liquidityprofitability relationship in business organizations: A study of selected quoted companies in Nigeria. British Journal of Economics, Finance and Management Sciences, 1(2), 11-29. 
Phillips, P. A., \& Sipahioglu, M. A. (2004). Performance implications of capital structure: Evidence from quoted UK organisations with hotel interests. The Service Industries Journal, 24(5), 31-51.

Priya, K., \& Nimalathasan, B. (2013). Liquidity management and profitability: A case study of listed manufacturing companies in Sri Lanka. International Journal of Technological Exploration and Learning, 2(4), 135-151.

Robb, A. M., \& Robinson, D. T. (2012). The capital structure decisions of new firms. Review of Financial Studies, 27(1), 153-179.

Rudin, M., Nurdin, D., \& Fattah, V. Y. (2016). The effect of liquidity and leverage on profitability of property and real estate company in Indonesian Stock Exchange. International Journal of Social Sciences and Management, 3(4), 300-304.

Ruland, W., \& Zhou, P. (2005). Debt, diversification, and valuation. Review of Quantitative Finance and Accounting, 25(3), 277-291.

Saleem, Q., \& Rehman, R. U. (2011). Impacts of liquidity ratios on profitability. Interdisciplinary Journal of Research in Business, 1(7), 95-98.

Sheel, A. (1994). Determinants of capital structure choice and empirics on leverage behavior: A comparative analysis of hotel and manufacturing firms. Journal of Hospitality \& Tourism Research, 17(3), 1-16.

Wijesundera, A. A. V. I., Weerasinghe, D. A. S., Krishna, T. P. C. R., Gunawardena, M. M. D., \& Peiris, H. R. I. (2016). Predictability of stock returns using financial ratios: Empirical evidence from Colombo stock exchange. Kelaniya Journal of Management, 4(2), 44-55.

Wippern, R. F. (1966). Financial structure and the value of the firm. The Journal of Finance, 21(4), 615-633.

Yoon, E., \& Jang, S. (2005). The effect of financial leverage on profitability and risk of restaurant firms. The Journal of Hospitality Financial Management, 13(1), 35-47. 